\title{
How To Diagnose and Manage Infected Endografts after Endovascular Aneurysm Repair
}

\author{
Carlo Setacci, MD ${ }^{1}$, Emiliano Chisci, $M D^{2 *}$, Francesco Setacci, MD³ , Leonardo Ercolini, MD², \\ Gianmarco de Donato, MD ${ }^{1}$, Nicola Troisi, MD $^{2}$, Giuseppe Galzerano, MD ${ }^{1}$, \\ Stefano Michelagnoli, $\mathrm{MD}^{2}$ \\ ${ }^{1}$ Vascular and Endovascular Surgery Unit, University of Siena, Siena, Italy; ${ }^{2}$ Department of Surgery, Vascular and Endovascular Surgery \\ Unit, "San Giovanni di Dio" Hospital, Florence, Italy; and ${ }^{3}$ P. Valdoni Department of Surgery, La Sapienza University, Rome, Italy
}

Based on a Presentation at the 2013 VEITH Symposium, November 19-23, 2013 (New York, NY, USA)

\begin{abstract}
The prevalence of endograft infections (EI) after endovascular abdominal aortic aneurysm repair is below $1 \%$. With the growing number of patients with aortic endografts and the aging population, the number of patients with El might also increase. The diagnosis is based on an association of clinical symptoms, imaging, and microbial cultures. Angio-computed tomography is currently the gold-standard technique for diagnosis. Low-grade infection sometimes requires nuclear medicine imaging to make a correct diagnosis. There is no good evidence to guide management so far. In the case of active gastrointestinal bleeding, pseudoaneurysm, or extensive perigraft purulence involving adjacent organs, an invasive treatment should always be attempted. In the other cases (the majority), when there is not an immediate danger to the patient's life, a conservative management is started with a proper antimicrobial therapy. Any infectious cavity can be percutaneously drained. Management depends on the patient's condition and a tailored approach should always be offered. In the case of a patient who is young, has a good life expectancy, or in whom there is absence of significant comorbidities, a surgical attempt can be proposed. Surgical techniques favor, in terms of mortality, patency, and reinfection rate, the in situ reconstruction. Choice of technique relies on the center and the operator's experience. Long-term antibiotic therapy is al-
\end{abstract}

\section{(c) 2014 Aorta.}

Published by Science International Corp. ISSN 2325-4637

Fax +1 2037853346

E-Mail: aorta@scienceinternational.org

http://aorta.scienceinternational.org
Accessible online at:

http://aorta.scienceinternational.org ways required in all cases, with close monitoring of the C-reactive protein.

Copyright $\odot 2014$ Science International Corp.

\section{Key Words}

Computed tomography scan - Aortic aneurysm - Epidemiology $\cdot$ Stent graft · Endovascular

\section{Introduction}

The incidence of infected endografts (IEs) following endovascular abdominal aortic aneurysm repair (EVAR) is below 1\% [1-113]. Most of our knowledge on diagnosis and management of IE is translated from the experience of graft infection following open repair [8-11].

As a complication, IE is one of the most challenging and threatening in vascular surgery and may lead to graft/arterial interface disruption, hemorrhage, or sepsis, and is associated with significant morbidity and mortality [12]. IEs have been shown to present roughly one-third as chronic sepsis, one-third as severe acute sepsis, and one-third as aorto-enteric fistula (AEF) $[6,7,11]$. IEs can be summed up as low- and high-grade infections [10].

Low-grade infection, caused by low-virulent bacteria, occurs generally late after the original graft im-

${ }^{*}$ Corresponding author:

Emiliano Chisci, MD

Department of Surgery

Vascular and Endovascular Surgery Unit

"San Giovanni di Dio" Hospital

50124 Florence, Italy

Tel.: +39 055693 2440, Fax: +39 055693 2670, E-Mail: e.chisci@gmail.com 
plantation. Usually, these patients have been suffering from nonspecific symptoms and signs, thus potentially delaying diagnosis. Nonspecific symptoms include weakness, weight loss, and malaise. Low-grade infection occurs in one third of total patients (chronic sepsis).

High-grade infection is caused by more aggressive bacteria. Symptoms appear acutely, such as sepsis, fever, abdominal pain, lumbar pain, graft thrombosis, septic embolism, hematemesis, rectal blood loss, and hemorrhagic shock (in the case of aorto-enteric fistula) $[10,11,14,15,101]$.

\section{Etiologies}

Experimental data [16-18] showed that stent grafts present lower bacterial resistance and greater bacterial adherence. Bacterial adherence depends on the length of stent graft in contact with the arterial wall and on the extent of endothelialization of the stent graft surface by mature collagen tissue.

Moreover, it has been speculated that an intact aneurysm wall in a patient with a stent graft prevents any bacterial egress and thus produces a more aggressive "closed space" infection. The presence of unevacuated thrombus around the graft could be a nidus for bacterial growth and, in case of endoleak, for septic embolism. Possible etiologies for IEs are perioperative contamination, hematogenous seeding, and mechanical erosion [11].

Secondary procedures with multiple catheter manipulations inside a stent graft have been found responsible for infection as well $[10,11,14]$.

The procedural environment is critical. It is thought that interventional radiology suites offer a lower level of sterility and require significant changes in both equipment [19] and work habits [20] to achieve outcomes similar to those in conventional operating rooms. However, it should be said that no correlation between procedures performed in the angiosuite versus the operating room has been confirmed by published studies [11,21].

Another risk factor associated with IEs is immunodeficiency (primary or secondary), especially that due to corticosteroid therapy or chemotherapy in neoplastic patients [22].

Urgent/emergency procedures are associated with a significantly higher percentage of IEs [14].
Antibiotic prophylaxis in vascular surgery has been proven beneficial to reduce surgical site infections after reconstruction of the aorta, procedures on the leg that involve a groin incision, any procedure that implants a vascular prosthesis, or endoluminal graft $[10,11,14,23,24]$. Therefore, prophylaxis with a cephalosporin or penicillin is mandatory.

The most frequent causative organism for IE is Staphylococcus $[9,11]$. Staphylococcus aureus has been reported to be the most frequently isolated microorganism in IE [7]. Many of these infections result from perioperative contamination, 50\% manifesting after the second year of follow-up. Development of stent graft infection in the presence of other infections has been reported. Bacteria are typically of skin flora or gastroenteric tract origin (including Staphylococcus aureus, Staphylococcus epidermidis, Escherichia coli, Enterococci, and Streptococci). Fungal infections are very rare $[10,11,94]$.

\section{Diagnosis}

IE diagnosis $[2,6,10,11,14,25-40,55,73,76]$ is based on an association of clinical symptoms, imaging findings, and microbial cultures. Cultures of blood or even samples collected from the infected field can sometimes be negative (up to $33 \%$ of cases) $[10,11,14]$.

Each patient should be investigated for leukocytosis and C-reactive protein values. C-reactive protein has been indicated as a value to be monitored in follow-up in order to grade infection (progression, resolution) and to decide when antibiotic therapy can be discontinued [25].

Angio-computed tomography (CT) scans should be performed in each patient, even in case of hemorrhagic shock. This scan has a high specificity and high sensitivity; it is performed quickly and is available in most centers. For all these reasons the angio-CT scan is considered the gold standard for IE. If an angio-CT scan is not conclusive for the diagnosis of a suspected $\mathrm{IE}$, and the patient's clinical condition is fit to await surgical treatment, MRI and positron emission tomography (PET) combined with $\mathrm{CT}$ should be considered $[10,11,26,27]$. Duplex ultrasound is rarely useful since it has low sensitivity and specificity in detecting IE.

High-grade infections are well diagnosed by angio-CT scan. Peculiar features are perigraft air, tissue infiltration, intrasac collections, fluid accumulation 
and soft-tissue attenuation, ectopic gas, pseudoaneurysm, or discontinuity of the aneurysmal wall, as well as focal bowel thickening, and direct contrast enhancement in the bowel in the arterial phase (communication between aortic wall and bowel tract) [27]. In case of aorto-enteric fistula, a CT scan confirms diagnosis in only $33-80 \%$ of cases. Also, endoscopy, rarely performed in the absence of gastrointestinal bleeding, does not exclude diagnosis if no fistula is seen. The diagnosis of aorto-enteric fistula is most often made on surgical exploration. Some problems arise when a low-grade infection without pathognomonic signs and symptoms is present. MRI has a higher sensitivity in the differentiation of small perigraft fluid collections [28].

Leukocyte scan or scintigraphy is most useful in low-grade infection, and in association with CT scan confirms the diagnosis of infection. Indium-111- and technetium-99-radiolabeled leukocytes have been employed to mark hot spots in suspected graft infection. Sensitivity and specificity range from 50 to $100 \%$ $[29,30]$. Fluorodeoxyglucose (FDG)-PET has been successfully used to detect suspected focal infection when other techniques are negative. To increase both sensitivity and specificity of this technique, the combination of FDG-PET and CT scan is used. Information gained by the exact localization of the site of infection provided by CT scan, combined with metabolic data obtained by FDG-PET, may enhance accurate localization and then treat the infectious process. When a focal intense FDG uptake plus a suspected lesion on CT imaging are present, the predicted prosthetic graft infection probability is around 97\% [31-39].

Isolation of the causative bacteria or fungus from either blood- or perigraft-drained fluid material is confirmative of the diagnosis of IE.

\section{Management}

The low incidence of this complication has not allowed establishment of a consensus in its management. IE management requires a case-by-case evaluation [1-113].

Patients undergoing EVAR are usually frail patients who are deemed unfit for open surgery due to anatomic or clinical features. The crucial point when there is an infected graft is to decide if the graft has to be removed or not. This decision has to take into account the patient's comorbidities, abdomen hostility (previous abdominal intervention, abdominal radiotherapy, colostomy, nephrostomy, etc), and symptoms and signs (including hemodynamic stability or instability).

Surgery is essential when there is active bleeding or threatening septic shock. Offering a therapeutic strategy should balance the operative risk and patient's life expectancy. On the other hand, the procedure likely to achieve better results in terms of mortality, morbidity and anatomic durability should be offered to the patient.

\section{Conservative Treatment}

In selected high-risk patients with multiple comorbidities with or without a hostile abdomen, conservative treatment is likely the only acceptable solution $[10,11,14,25,26,40-43,64-69,85-87,90,92]$. Sometimes, it is better to cope with suboptimal therapy, as in conservative treatments, and allow the patient some more life years than to be extremely radical [87]. In Italy, the mean life expectancy of a healthy man is a little bit more than 82 years, therefore, in the case of an 80-year-old man with an infected abdominal aortic aneurysm endograft, hypertension, cardiomyopathy, and even renal insufficiency, it is unlikely to give more years to live than Nature has given to that patient (primum non nॅoc[macr]ere).

Conservative treatment consists of antimicrobial therapy, which should not be empirical but based on the antibiogram and percutaneous drainage (CT guided). For somewhat more aggressive therapy, drainage may be followed by irrigation and extraction of infectious material from the cavity. In selected cases, simple resection of the aneurysm sac has been described, leaving the stent graft behind [42]. Mortality in these frail patients has been up to $40 \%$ [43].

Although the consensus is that, in suitable patients, the infected graft material should always be removed, some authors [14] showed no significant difference in mortality between the conservatively and surgically managed groups (possibly related to the small sample size analyzed) [43]. Cernohorsky et al. [14] concluded their study by saying that there may be a role for conservative treatment in selected cases of patients with stent-graft infection, possibly those patients with minor, low-grade infections.

On the contrary, Lyons et al. [4] recently reported that in their large series all patients (abdominal and thoracic) who did not have their endografts explanted died of aortic disease progression, contrasted with a 
mortality rate of only about $30 \%$ when the graft was explanted.

\section{Surgical Treatment}

When an infected graft is generating a clinical scenario that is not manageable by a conservative approach, surgical treatment should be considered [2$16,26,40-113]$. Young patients with a good life expectancy (these are a minority) should be considered for surgical treatment as the first option.

Surgical treatment consists of two different phases: the stent-graft removal and revascularization. Stent graft removal is a prerequisite for complete healing and cure of the infectious process in a patient with a vascular graft implant [2-16,26,40-113]. The technical aspects of device explantation will vary with the type of graft deployed and the vascular anatomy. Endografts with suprarenal barb fixation require supraceliac control for explantation, whereas endografts with an infrarenal fixation may be managed with a lower clamp placement. In case of endograft with suprarenal barb fixation, supraceliac clamping is required and the bare suprarenal struts of the device may be cut and left in situ [11,102]. In order to facilitate graft removal, a suggested procedure is to routinely dislodge the proximal portion of the stent graft, squeezing the upper stent and gently pushing the stent hooks or barbs in a proximal direction [11]. Dissection of the pararenal aorta and iliac arteries is often described as very difficult, because of the inflammation surrounding the arteries near the graft attachment sites, with a reactive process similar to that encountered with an inflammatory aneurysm.

After excision of the infected graft and debridement of devitalized tissue, in situ or by extraanatomical routes, reconstruction can be accomplished supported by pre-, intra-, and postoperative broad-spectrum or culture-specific antibiotic therapy $[10,89]$.

The specific revascularization technique currently is based on the experience of the operators and center.

Extra-anatomic bypass (EAB) originating from the axillary artery has been performed widely. The most common reconstruction employed is the axillofemoro-femoral bypass performed in the same or a later staged procedure. Several authors [7-11,70-75] have reported substantially lower mortality rates with staged $E A B$ and graft removal. Dacron or polytetra- fluoroethylene grafts, as well as autologous vein or cryopreserved allograft, can be used.

Concerns about long-term graft patency and reinfection (up to $27 \%$ ) remain, as well as the risk of aortic stump blow-out during follow-up (up to $25 \%$ ), in particular in cases of persistent retroperitoneal sepsis $[10,11]$. Specific follow-up protocols should be applied in order to detect early signs of this fatal complication. Risk of renal complications (renal artery occlusion) has also been described in cases of aortic stump closure. The risk of amputation is reported as high as 29\% [92]. In a single center experience, reported mortality for EAB was around $16 \%$ while in situ reconstruction mortality was nearly $6 \%$. This may have been due to the preference for performing $E A B$ in high-grade infection [7].

In situ reconstruction avoids aortic stump oversewing, and presents other advantages as well. It avoids the risk of stump blow-out and renal vessel occlusion, avoids prolonged operative time and consequent ischemia, reduces limb loss, and finally avoids longterm anticoagulation associated with EAB.

A recent review reported that in situ reconstructions have surpassed EAB in almost every aspect (mortality, amputation rate, patency) [93]. After having held the position of gold standard for years, EAB is now part of a wide array of treatment options with limited indications [93].

In case of in situ reconstruction, cadaveric homograft tissue has been used in some centers $[95,96]$. This technique has a lower rate of reinfection $(<10 \%)$, perianastomotic hemorrhage $(<10 \%)$, thrombosis $(<10 \%)$ and recurrent aneurysm formation $(2 \%)$ compared to EAB.

The well known major drawback of cryopreserved human tissue is the risk of degeneration of the allograft, leading to complications such as calcification, dilatation, or even rupture of the allograft [97]. Dilation has been reported in up to $17 \%$ of cases and late occlusion rates in up to $32 \%$ [98]. Immunological reactions seem to be partly responsible for degenerative changes occurring in the allograft wall [99]. Moreover, we cannot generalize that in situ allograft replacement is safe for all types of infection. Indeed caution should be used when planning in situ allograft replacement in patients with extensive infection and gross purulence or highly virulent Gramnegative organisms. In these cases, some authors have preferred complete graft removal, extensive debridement, and EAB [97]. EAB continues to be recommended 
when there is a severe, widespread purulent abdominal infection.

In the largest study of cryopreserved aorto-iliac arterial allografts (220 patients), [14] the authors concluded that this treatment allows for in-line aortic reconstruction in the presence of infection, with lower patient morbidity (24\%) and mortality (9\%) than other published treatment options. In the long term, use of cryopreserved grafts is associated with low rates of aneurysm formation (3\%), allograft rupture $(6 \%)$, recurrent infection (4\%), and early limb loss (0\%). Freedom from graft-related complications, graft explant, and limb loss was $80 \%, 88 \%$, and $97 \%$, respectively, at five years. The use of a fresh allograft has been discontinued in most institutions due to concerns regarding the graft's propensity to dilate over the long term [100].

At present, reconstruction with cryopreserved arterial allografts can be regarded as a safe temporizing maneuver to help eradicate infection and permit subsequent reconstruction with prosthetic material when necessary (bridge solutions) $[97,101]$. Superficial femoral-popliteal veins in a nonreversed configuration have been used as material for aorto-iliac reconstruction in case of infected stent graft explantation [7]. Some authors called this technique of revascularization a neoartoiliac system procedure. Advantages include avoiding the risk of aortic stump blow-out and the potential patency and reinfection issues of EAB. Thirty-day operative mortality is $<10 \%$, with 5 -year mortality rates of $30-50 \%$. Thirty-day major amputation rates range from $2 \%$ to $9 \%$, with 5 -year limbsalvage rates ranging between $89 \%$ and $96 \%$. Recurrent infection is very rare, occurring in $<2 \%$ of patients [103]. Venous morbidity is similarly low, with fasciotomy rates of $12 \%$, and only $15 \%$ of patients experiencing chronic venous insufficiency at five years. Incidence of postoperative deep vein thrombosis is up to $22 \%$ for the donor limb [26]. Aneurysmal degeneration is also exceptionally rare. Use of autologous vein grafts for in situ reconstruction of infected grafts represents the standard of care in the treatment of aortic graft infections according to a recent review from Chung and Clagett [103]. In the literature, autogenous veins remain the most effective method to avoid any reinfection. Important factors limiting their applicability are extended surgical trauma (risk of wound infection) and longer operation time $[8,103,104]$.
Some researchers have used antibiotic-impregnated grafts and Dacron silver grafts in order to decrease the risk of infection recurrence (combined with adequate antimicrobial therapy) $[105,106]$. The reported reinfection rate ranges from 4 to $22 \%[6,106-$ 109]. Thirty-day mortality ranges from 7 to $21 \%$ and morbidity from 2 to $60 \%$. The 5 -year survival is near $50 \%$. Amputations are rarely seen in these cases (they are more common following EAB). In a recent paper, [98] cryopreserved arterial homografts were compared to silver-coated grafts, showing no statistical differences between the two groups in terms of early mortality and midterm survival. It was found that homografts are nearly three times more expensive than silver grafts. These authors [98] reported homograft as the preferred implantation in patients without an acute life-threatening status (i.e., gastrointestinal bleeding, free aneurysm rupture, cardiogenic shock) even if more expensive and despite no statistical differences being found in the results.

In a meta-analysis, [6] rifampicin-bonded grafts are associated with fewer amputations, conduit failures, and early mortality than other treatment modalities for aortic graft infection. On the contrary, reinfection was worst for rifampicin-bonded grafts (closely followed by cryopreserved allografts), and lowest for autogenous veins. This systematic review and metaanalysis remarked that in situ replacement may be appropriate in properly selected patients for infected vascular grafts and raised the question whether $E A B$ should remain the gold standard as it was in the past.

Additional strategies during surgery for infected aortic grafts and endografts are used to prevent reinfection: use of viable flaps to obliterate dead space, or of omentum tacked to the aortic stump to reduce risk of blow-out, as well as placement of perigraft catheters for postoperative antibiotic irrigation. Fatima et al. [92] reported Rifampin-soaked polyester grafts wrapped $360^{\circ}$ in autogenous tissue (preferably omentum) $[4,19,110]$.

Some authors indicate the need for lifelong appropriate parenteral antibiotic prophylaxis in all patients with prosthetic aortic grafts who are undergoing a late procedure that can cause bacteremia [25].

The duration of antimicrobial treatment in patients after removal of an infected aortic endograft is controversial. No current guidelines exist on this issue and some authors suggest prolonging antibiotic adminis- 
tration until the C-reactive protein level has returned to baseline [25].

The most-preferred antibiotic agents are daptomycin for Gram-positive coverage and piperacillintazobactam, cefepime, or levofloxacin for Gramnegative coverage. Vancomycin or linezolid is an alternative for staphylococcal and MRSA (methicillinresistant Staphylococcus aureus) coverage [111,112].

\section{Aorto-enteric Fistula}

Aorto-enteric fistulas (AEFs) are rare, lethal causes of massive gastrointestinal tract bleeding $[10,11]$ and among the most challenging diagnostic and therapeutic problems encountered by vascular surgeons. The morbidity and mortality remain alarmingly high.

The treatment aim is to promptly stop bleeding. The fastest way may be via a further endovascular exclusion by placement of a new endograft to cover the hole in the gastrointestinal tract [89]. This procedure should be considered as "bridge solution" to a more definitive one. Relining should be considered if anatomic criteria are respected inside the AEF. As we know, the source of infection and so the fistulous communication cannot be removed in this way and the infection cannot be solved even with aggressive antibiotic therapy. In the literature, anecdotal attempts to achieve definitive solutions in this way have failed in the long-term and new surgery has been required $[12,101]$.

If the endovascular solution is not possible, open surgery is required (details of surgical techniques are given in the Surgical Treatment section). When the bleeding has been stopped, conventional treatment of an AEF is based on debridement, repair of the enteric fistula, and removal of the inciting factor. In the literature, anatomic bypass (antibiotic-impregnated or silver-coated prosthesis, homograft or allo- graft), and extra-anatomic bypass (axillo-bifemoral bypass) are all described $[4,7,8,10,11,113]$.

\section{Summary}

The prevalence of endograft infections after endovascular abdominal aortic aneurysm repair is below $1 \%$. With the growing number of patients with aortic endografts and the aging population, the number of patients with endograft infections can be expected to increase. The diagnosis is based on an association of clinical symptoms, imaging findings, and microbial cultures. Angio-CT is currently the gold-standard technique for diagnosis. Low-grade infection sometimes requires nuclear medicine imaging to make a correct diagnosis. There is no good evidence to guide management so far. In case of active gastrointestinal bleeding, pseudoaneurysm, or extensive perigraft purulence involving adjacent organs, an invasive treatment should always be attempted. In the other cases (the majority), when there is no immediate danger to the patient's life, a conservative management can be started with appropriate antimicrobial therapy. In case of an infectious cavity, this could be percutaneously drained. Specific management depends on the patient's condition and a tailored approach should always be offered. In case of a young age and good life expectancy without significant comorbidities, a surgical attempt should be proposed. Surgical techniques favor (in terms of mortality, patency and reinfection rate) an in situ reconstruction. Currently, the choice of technique used relies on center and operator experience. Long-term antibiotic therapy is always required in all cases, with close monitoring of the C-reactive protein.

\section{Conflict of Interest}

The authors have no conflict of interest relevant to this publication.

Comment on this Article or Ask a Question

\section{References}

1. Chalmers N, Eadington DW, Gandanhamo D, Gillespie IN, Ruckley CV. Case report: infected false aneurysm at the site of an iliac stent. Br J Radiol. 1993;66:946-948. 10.1259/0007-1285-66-790-946

2. Numan F, Gulsen F, Solak S, Cantasdemir M. Management of endograft infections. J Cardiovasc Surg (Torino). 2011;52:205-223.

3. Laser A, Baker N, Rectenwald J, Eliason JL, 5 . Criado-Pallares E, Upchurch GR Jr. Graft in- fection after endovascular abdominal aortic aneurysm repair. J Vasc Surg. 2011;54: 58-63. 10.1016/j.jvs.2010.11.111

4. Lyons OT, Patel AS, Saha P, Clough RE, Price N, Taylor PR. A 14-year experience with aortic endograft infection: management and results. Eur J Vasc Endovasc Surg. 2013; 46:306-313. 10.1016/j.ejvs.2013.04.021

Harlander-Locke MP, Harmon LK, Lawrence 7. $\mathrm{PF}$, Oderich GS, McCready RA, Morasch MD, et al. The use of cryopreserved aortoiliac allograft for aortic reconstruction in the United States. J Vasc Surg. 2014;59:669674.e1. 10.1016/j.jvs.2013.09.009

6. Hobbs SD, Kumar S, Gilling-Smith GL. Epidemiology and diagnosis of endograft infection. J Cardiovasc Surg (Torino). 2010;51: 5-14.

7. Ducasse E, Calisti A, Speziale F, Rizzo L, Misuraca M, Fiorani P. Aortoiliac stent graft 
infection: current problems and management. Ann Vasc Surg. 2004;18:521-526. 10. 1007/s10016-004-0075-9

8. O'Connor S, Andrew P, Batt M, Becquemin JP. A systematic review and meta-analysis of treatments for aortic graft infection. J Vasc Surg. 2006;44:38-45.e8. 10.1016/j.jvs. 2006.02.053

9. Hallett JW, Marshall DM, Petterson TM, Gray DT, Bower TC, Cherry KJ, et al. Graftrelated complications after abdominal aortic aneurysm repair: reassurance from a 36year population-based experience. J Vasc Surg. 1997;25:277-284. 10.1016/S07415214(97)70349-5

10. Capoccia L, Mestres G, Riambau V. Current technology for the treatment of infection following abdominal aortic aneurysm (AAA) fixation by endovascular repair (EVAR). J Cardiovasc Surg (Torino). 2014;55: 381-389.

11. Setacci C, De Donato G, Setacci F, Chisci E, Perulli A, Galzerano G, et al. Management of abdominal endograft infection. J Cardiovasc Surg (Torino). 2010;51:33-41.

12. McCready RA, Bryant MA, Divelbiss JL, Chess BA, Chitwood RW, Paget DS. Arterial infections in the new millenium: an old problem revisited. Ann Vasc Surg. 2006;20: 590-595. 10.1007/S10016-006-9107-y

13. Saleem BR, Berger P, Zeebregts CJ, Slart RH, Verhoeven EL, van den Dungen JJ. Periaortic endograft infection due to Listeria monocytogenes treated with graft preservation. J Vasc Surg. 2008;47:635-637. 10. 1016/j.jvs.2007.09.029

14. Cernohorsky P, Reijnen MM, Tielliu IF, van Sterkenburg SM, van den Dungen JJ, Zeebregts $C J$. The relevance of aortic endograft prosthetic infection. J Vasc Surg. 2011;54: 327-333. 10.1016/j.jvs.2010.12.067

15. Fiorani $P$, Speziale $F$, Calisti A, Misuraca M, Zaccagnini D, Rizzo L, et al. Endovascular graft infection: preliminary results of an international enquiry. J Endovasc Ther. 2003;10:919-927. 10. 1583/1545-1550(2003)010<0919:EGIPRO > 2.0. $\mathrm{CO} ; 2$

16. Parsons RE, Sanchez LA, Marin ML, Holbrook KA, Faries PL, Suggs WD, et al. Comparison of endovascular and conventiona vascular prostheses in an experimental infection model. J Vasc Surg. 1996;24:920925; discussion 925-926. 10.1016/S07415214(96)70037-X

17. Thibodeaux LC, James KV, Lohr JM, Welling $\mathrm{RE}$, Roberts WH. Infection of endovascular stents in a swine model. Am J Surg. 1996;172: 151-154. 10.1016/S0002-9610(96)00139-0

18. Hearn AT, James KV, Lohr JM, Thibodeaux LC, Roberts WH, Welling RE. Endovascular stent infection with delayed bacterial challenge. Am J Surg. 1997;174:157-159. 10. 1016/S0002-9610(97)90075-1
19. Dietrich EB. Endovascular intervention suite design In: White RA, Fogarty TJ. Peripheral Endovascular Interventions. St. Louis: Mosby; 1996, p. 129-139.

20. Joffre F, Otal P, d'Othée BJ. Plea for a "surgical conscience" in the interventional radiology suite. Cardiovasc Intervent Radiol. 1998;21:445-447. 10.1007/s002709900300

21. Nouwen JL, Wielenga JJ, van Overhagen $H$, Laméris JS, Kluytmans JA, Behrendt MD, et al. Hickman catheter-related infections in neutropenic patients: insertion in the operating theater versus insertion in the radiology suite. J Clin Oncol. 1999;17:1304.

22. Aho PS, Roth WD, Keto $P$, Lepäntalo $M$. Early elective conversion for failing EVAR. Scand J Surg. 2005;94:221-226.

23. Bandyk DF. Antibiotics-why so many and when should we use them? Semin Vasc Surg. 2002;15:268-274. 10.1053/svas.2002. 36262

24. Kirksey L, Brener BJ, Hertz S, Parsonnet V. Prophylactic antibiotics prior to bacteremia decrease endovascular graft infection in dogs. Vasc Endovascular Surg. 2002;36: 171-178. 10.1177/153857440203600303

25. Brouw LW, van Weerelt CT, van Guldener C, Geenen GP, van der Laan L. Non invasive treatment of peri-aortic inflammation after endovascular graft. Eur J Vasc Endovasc Surg. 2007;34:179-181. 10.1016/j.ejvs.2007. 02.007

26. Perera GB, Fujitani RM, Kubaska SM. Aortic graft infection: update on management and treatment options. Vasc Endovascular Surg. 2006;40:1-10. 10.1177/153857440604000101

27. Orton DF, LeVeen RF, Saigh JA, Culp WC, Fidler JL, Lynch TJ, et al. Aortic prosthetic graft infections: radiologic manifestations and implications for management. Radiographics. 2000;20:977-993. 10.1148/ radiographics.20.4.g00j112977

28. Shahidi S, Eskil A, Lundof E, Klaerke A, Jensen BS. Detection of abdominal aortic graft infection: comparison of magnetic resonance imaging and indium-labeled white blood cell scanning. Ann Vasc Surg. 2007; 21:586-592. 10.1016/j.avsg.2007.03.018

29. Speziale F, Calisti A, Zaccagnini D, Rizzo L, Fiorani $P$. The value of technetium-99m HMPAO leukocyte scintigraphy in infectious abdominal aortic aneurysm stent graft complications. J Vasc Surg. 2002;35: 1306-1307. 10.1067/mva.2002.123747

30. Fiorani P, Speziale F, Rizzo L, De Santis F, Massimi GJ, Taurino M, et al. Detection of aortic graft infection with leukocytes labeled with technetium 99m-hexametazime. J Vasc Surg. 1993;17:87-95. 10.1016/ 0741-5214(93)90012-B

31. Bruggink JL, Glaudemans AW, Saleem BR, Meerwaldt R, Alkefaji $H$, Prins TR, et al. Accuracy of FDG-PET-CT in the diagnostic work-up of vascular prosthetic graft infection. Eur J Vasc Endovasc Surg. 2010;40: 348-354. 10.1016/j.ejvs.2010.05.016

32. Fukuchi $K$, Ishida $Y$, Higashi M, Tsunekawa $\mathrm{T}$, Ogino $\mathrm{H}$, Minatoya $\mathrm{K}$, et al. Detection of aortic graft infection by fluorodeoxyglucose positron emission tomography: comparison with computed tomographic findings. J Vasc Surg. 2005;42:919-925. 10.1016/ j.jvs.2005.07.038

33. Tokuda Y, Oshima H, Araki Y, Narita Y, Mutsuga $M$, Kato $K$, et al. Detection of thoracic aortic prosthetic graft infection with $18 \mathrm{~F}$ fluorodeoxyglucose positron emission tomography/computed tomography. Eur J Cardiothorac Surg. 2013;43:1183-1187. 10. 1093/ejcts/ezs693

34. Spacek M, Belohlavek O, Votrubova J, Sebesta P, Stadler P. Diagnostics of "non-acute" vascular prosthesis infection using 18F-FDG PET/CT: our experience with 96 prostheses. Eur J Nucl Med Mol Imaging. 2009;36:850858. 10.1007/s00259-008-1002-z

35. Lauwers P, Van den Broeck S, Carp L, Hendriks J, Van Schil P, Blockx P. The use of positron emission tomography with (18)Ffluorodeoxyglucose for the diagnosis of vascular graft infection. Angiology. 2007; 58:717-724. 10.1177/0003319707299205

36. Keidar Z, Engel A, Hoffman A, Israel O, Nitecki $S$. Prosthetic vascular graft infection: the role of $18 \mathrm{~F}-\mathrm{FDG}$ PET/CT. J Nucl Med. 2007;48:1230-1236. 10.2967/jnumed.107. 040253

37. Tegler G, Sörensen J, Björck M, Savitcheva I, Wanhainen A. Detection of aortic graft infection by 18 -fluorodeoxyglucose positron emission tomography combined with computed tomography. J Vasc Surg. 2007;45: 828-830. 10.1016/j.jvs.2006.12.018

38. Štádler P, Billohlávek $O$, Špaček M, Michálek $P$. Diagnosis of vascular prosthesis infection with FDG-PET/CT. J Vasc Surg. 2004;40: 1246-1247. 10.1016/j.jvs.2004.09.032

39. Balink $H$, Reijnen MM. Diagnosis of abdominal aortic prosthesis infection with FDGPET/CT. Vasc Endovascular Surg. 2007:41: 428-432. 10.1177/1538574407305094

40. Herdrich BJ, Fairman RM. How to manage infected aortic endografts. J Cardiovasc Surg (Torino). 2013;54:595-604.

41. Hart JP, Eginton MT, Brown KR, Seabrook $G R$, Lewis $B D$, Edmiston $C E$, et al. Operative strategies in aortic graft infections: is complete graft excision always necessary? Ann Vasc Surg. 2005;19:154-160. 10.1007/s10016-004-0168-5

42. Malina M. Infected endografts: they do not all have to be removed: an effective alternate strategy which can work. Oral Presentation at VEITH Symposium 2008, November 20, 2008.

43. Turney EJ, Steenberge SP, Lyden SP, Eagleton MJ, Srivastava SD, Sarac TP, et al. Late 
graft explants in endovascular aneurysm repair. J Vasc Surg. 2014;59:886-893. 10. 1016/j.jvs.2013.10.079

44. Weymann A, Ruhparwar A, Karck M. Management of abdominal stent graft infection with cryopreserved aortic allograft. Asian Cardiovasc Thorac Ann. 10.1177/ 0218492314532848

45. Charlton-Ouw KM, Sandhu HK, Huang G, Leake SS, Miller CC 3rd, Estrera AL, et al. Reinfection after resection and revascularization of infected infrarenal abdominal aortic grafts. J Vasc Surg. 2014;59:684-692. 10.1016/j.jvs.2013.09.030

46. Klonaris C, Lioudaki S, Katsargyris A, Psathas E, Kouvelos G, Doulaptsis M, et al. Late open conversion after failed endovascular aortic aneurysm repair. J Vasc Surg. 2014;59:291-297. 10.1016/j.jvs.2013.07.106

47. Arya S, Coleman DM, Knepper J, Henke PK, Upchurch GR, Rectenwald JE, et al. Outcomes after late explantation of aortic endografts depend on indication for explantation. Ann Vasc Surg. 2013;27:865-873. 10. 1016/j.avsg.2013.03.009

48. Mizoguchi $\mathrm{H}$, lida $\mathrm{O}$, Dohi $\mathrm{T}$, Tomoda $\mathrm{K}$, Kimura $\mathrm{H}$, Inoue $\mathrm{K}$, et al. Abdominal aortic aneurysmal and endovascular device infection with iliopsoas abscess caused by Mycobacterium bovis as a complication of intravesical bacillus Calmette-Guérin therapy. AnnVascSurg.2013;27:1186.e1-e5.10.1016/ j.avsg.2012.12.004

49. Kordzadeh A, Rhodes KM, Hanif MA, Scott H, Panayiotopoulos Y. Ruptured cryptogenic mycotic abdominal aortic aneurysm by Salmonella enteritidis. Ann Vasc Surg. 2013; 27:973.e9-e17. 10.1016/j.avsg.2012.08.016

50. Harlock JA, Qadura M, Lee G, Szalay DA. Infected aortic stent graft with Propionibacterium acnes. Vasc Endovascular Surg. 2013;47: 394-396. 10.1177/1538574413487262

51. Wheeler HK, Quiroga E, Kohler TR, Tang GL. Mycotic aortic aneurysm caused by Haemophilus influenzae group F. Ann Vasc Surg. 2013;27:353.e13-e16. 10.1016/j.avsg. 2012.05.029

52. Kao YT, Shih CM, Lin FY, Tsao NW, Chang NC, Huang CY. An endoluminal aortic prosthesis infection presenting as pneumoaorta and aortoduodenal fistula. World J Gastroenterol. 2012;18:5309-5311. 10.3748/wjg. v18.i37.5309

53. Lowe C, Chan A, Wilde N, Hardy S. Infected endovascular aneurysm repair graft complicated by vertebral osteomyelitis. J Vasc Surg. 2012;56:826-828. 10.1016/j.jvs.2012. 03.268

54. Veger HT, Hedeman Joosten PP, Thoma SR, Visser MJ. Infection of endovascular abdominal aortic aneurysm stent graft after urosepsis: case report and review of the literature. Vascular. 2013;21:10-13.10.1258/ vasc.2011.cr0294

55. Phade SV, Keldahl ML, Morasch MD, Rodriguez HE, Pearce WH, Kibbe MR, et al. Late abdominal aortic endograft explants: indications and outcomes. Surgery. 2011;150: 788-795. 10.1016/j.surg.2011.07.061

56. Van den Eynde W, van Riel W, Nevelsteen A, Daenen G. Aorto-iliac stent graft infection complicated by endotension and consequent rupture of the aneurysmal sac: a case report. Acta Chir Belg. 2011;111:246249.

57. Parmar J, Winterbottom A, Cooke F, Lever AM, Gaunt M. Endovascular aortic stent graft infection with Streptococcus equi: the first documented case. Vascular. 2013;21: 14-16. 10.1258/vasc.2010.cr0258

58. Kritpracha B, Premprabha D, Sungsiri J, Tantarattanapong W, Rookkapan S, Juntarapatin P. Endovascular therapy for infected aortic aneurysms. J Vasc Surg. 2011;54:1259-1265. 10.1016/j.jvs.2011.03. 301

59. Halak M, Heldenberg E, Silverberg D, Schneiderman J. Clostridium septicum postendovascular aneurysm repair stent-graft infection. Vascular. 2012;20:104-106. 10. 1258/vasc.2010.cr0245

60. Shibutani S, Obara H, Ono S, Kakefuda T, Kitagawa Y. Complete removal of infected abdominal aortic stent-graft with suprarenal fixation. Ann Vasc Surg. 2011;25: 980.e7-e10. 10.1016/j.avsg.2011.01.011

61. Colwick SE, Alkhoury F, Martin JT, Ferneini AM. Abdominal aortic aneurysm repair complicated by infection with Clostridium septicum. Ann Vasc Surg. 2011;25:839.e11e13. 10.1016/j.avsg.2010.12.042

62. Brinster CJ, Fairman RM, Woo EY, Wang GJ, Carpenter JP, Jackson BM. Late open conversion and explantation of abdominal aortic stent grafts. J Vasc Surg. 2011;54:42-46. 10.1016/j.jvs.2010.12.042

63. Piffaretti G, Rivolta N, Mariscalco G, Tozzi M, Maida S, Castelli P. Aortic endograft infection: a report of 2 cases. Int J Surg. 2010;8: 216-220. 10.1016/j.ijsu.2009.12.011

64. Blanch M, Berjón J, Vila R, Simeon JM, Romera A, Riera $S$, et al. The management of aortic stent-graft infection: endograft removal versus conservative treatment. Ann Vasc Surg. 2010;24:554.e1-e5. 10.1016/j.avsg.2009.11. 003

65. Gardner GP, Morris ME, Makamson B, Faizer RM. Infection of an aortic stent graft with suprarenal fixation. Ann Vasc Surg. 2010;24: 418.e1-e6. 10.1016/j.avsg.2009.08.015

66. Lawrence PF. Conservative treatment of aortic graft infection. Semin Vasc Surg. 2011;24:199-204. 10.1053/j.semvascsurg. 2011.10.014
67. Clough RE, Black SA, Lyons OT, Zayed HA, Bell RE, Carrell T, et al. Is endovascular repair of mycotic aortic aneurysms a durable treatment option? Eur J Vasc Endovasc Surg. 2009;37:407-412. 10.1016/j.ejvs.2008. 11.025

68. Lyons O, Patel AS, Taylor PR. Aortic endograft explantation. In: Davies M, Lumsden AB. Contemporary Endovascular Management: Aorta. Minneapolis, MN: Cardiotext Publishing; 2013.

69. Hulin SJ, Morris GE. Aortic endograft infection: open surgical management with endograft preservation. Eur J Vasc Endovasc Surg. 2007;34:191-193. 10.1016/j.ejvs.2007. 03.003

70. Kloppenburg GT, van de Pavoordt ED, de Vries JP. Endograft-preserving therapy of a patient with Coxiella burnetii-infected abdominal aortic aneurysm: a case report. J Med Case Rep. 2011;5:565. 10.1186/17521947-5-565

71. Cairols MA, Simeon JM, Guerrero F, Barjau $E$, Iborra $E$. Infected grafts require excision and extra-anatomic reconstruction: for the motion. In: Greenhalgh RM. The Evidence for Vascular or Endovascular Reconstruction. Philadelphia: WB Saunders; 2002, p. 246-259.

72. Krysa J, Taylor PR. Explantation of aortic infrarenal stent graft. Ann R Coll Surg Engl. 2012;94:365-366. 10.1308/ 003588412X13373405385214i

73. Jamel S, Attia R, Young C. Management of an infected aortic graft with endovascular stent grafting. Diagn Interv Radiol. 2013;19: 66-69. 10.4261/1305-3825.DIR.5070-12.1

74. May J, White GH, Harris JP. Techniques for surgical conversion of aortic endoprosthesis. Eur J Vasc Endovasc Surg. 1999;18:284289. 10.1053/ejvs.1999.0898

75. Oderich GS, Bower TC, Cherry KJ Jr, Panneton JM, Sullivan TM, Noel AA, et al. Evolution from axillofemoral to in situ prosthetic reconstruction for the treatment of aortic graft infections at a single center. J Vasc Surg. 2006;43:1166-1174. 10.1016/j. jvs.2006.02.040

76. Moulakakis KG, Dalainas I, Mylonas S, Giannakopoulos TG, Avgerinos ED, Liapis CD. Conversion to open repair after endografting for abdominal aortic aneurysm: a review of causes, incidence, results, and surgical techniques of reconstruction. J Endovasc Ther. 2010;17:694-702. 10.1583/ 1545-1550-17.6.694

77. Blaisdell FW, Hall AD, Lim RC Jr, Moore WC. Aorto-iliac arterial substitution utilizing subcutaneous grafts. Ann Surg. 1970;172: 775-780. 10.1097/00000658-19701100000001

78. van Zitteren $M$, van der Steenhoven $T J$, Burger DH, van Berge Henegouwen DP, 
Heyligers JM, Vriens PW. Spiral vein reconstruction of the infected abdominal aorta using the greater saphenous vein: preliminary results of the Tilburg experience. Eur $J$ Vasc Endovasc Surg. 2011;41:637-646. 10. 1016/j.ejvs.2011.01.020

79. Beck AW, Murphy EH, Hocking JA, Timaran $\mathrm{CH}$, Arko FR, Clagett GP. Aortic reconstruction with femoral-popliteal vein: graft stenosis incidence, risk and reintervention. VascSurg.2008;47:36-44.10.1016/j.jvs.2007. 08.035

80. Lehnert T, Gruber HP, Maeder N, Allenberg JR. Management of primary aortic graft infection by extra-anatomic bypass reconstruction. Eur J Vasc Surg. 1993;7:301-307. 10.1016/S0950-821X(05)80013-1

81. Brown KE, Heyer K, Rodriguez H, Eskandari MK, Pearce WH, Morasch MD. Arterial reconstruction with cryopreserved human allografts in the setting of infection: a singlecenter experience with midterm follow-up. J Vasc Surg. 2009;49:660-666. 10.1016/j.jvs. 2008.10.026

82. Vogt PR, Brunner-La Rocca HP, Carrel T, von Segesser LK, Ruef C, Debatin J, et al. Cryopreserved arterial allografts in the treatment of major vascular infection: a comparison with conventional surgical techniques. J Thorac Cardiovasc Surg. 1998;116:965972. $10.1016 /$ S0022-5223(98)70048-0

83. Uchida N, Katayama A, Tamura K, Miwa S, Masatsugu K, Sueda T. In situ replacement for mycotic aneurysms on the thoracic and abdominal aorta using rifampicin-bonded grafting and omental pedicle grafting. Ann Thorac Surg. 2012;93:438-442. 10.1016/j. athoracsur.2011.07.050

84. Dulbecco E, Camporrotondo M, Blanco G, Haberman D. In situ reconstruction with bovine pericardial tubular graft for aortic graft infection. Rev Bras Cir Cardiovasc. 2010;25:249-252. 10.1590/S0102-76382010000200020

85. Morris GE, Friend PJ, Vassallo DJ, Farrington $M$, Leapman S, Quick CR. Antibiotic irrigation and conservative surgery for major aortic graft infection. J Vasc Surg. 1994:20: 88-95. 10.1016/0741-5214(94)90179-1

86. Frano is $\mathrm{F}$, Thevenet $\mathrm{A}$. Conservative treatment of prosthetic aortic graft infection with irrigation. Ann Vasc Surg. 1991;5:199201. 10.1007/BF02016757

87. Kan CD, Lee $H L$, Yang YJ. Outcome after endovascular stent graft treatment for mycotic aortic aneurysm: a systematic review. J Vasc Surg. 2007;46:906-912. 10.1016/j.jvs. 2007.07.025

88. Antoniou GA, Koutsias S, Antoniou SA, Georgiakakis A, Lazarides MK, Giannoukas AD. Outcome after endovascular stent graft repair of aortoenteric fistula: a systematic review. J Vasc Surg. 2009;49:782-789. 10. 1016/j.jvs.2008.08.068
89. Setacci C, de Donato G, Setacci F. Endografts for the treatment of aortic infection. Semin Vasc Surg. 2011;24:242-249. 10. 1053/j.semvascsurg.2011.10.009

90. Pryluck DS, Kovacs S, Maldonado TS, Jacobowitz GR, Adelman MA, Charles HC, et al. Percutaneous drainage of aortic aneurysm sac abscesses following endovascular aneurysm repair. Vasc Endovascular Surg. 2010;44:701707. 10.1177/1538574410376451

91. Sharif MA, Lee B, Lau LL, Ellis PK, Collins AJ, Blair $\mathrm{PH}$, et al. Prosthetic stent graft infection after endovascular abdominal aortic aneurysm repair. J Vasc Surg. 2007;46:442448. 10.1016/j.jvs.2007.05.027

92. Fatima J, Duncan AA, de Grandis E, Oderich GS, Kalra M, Gloviczki P, Bower TC. Treatment strategies and outcomes in patients with infected aortic endografts. J Vasc Surg. 2013;58:371-379. 10.1016/j.jvs.2013. 01.047

93. Berger $\mathrm{P}$, Moll FL. Aortic graft infections: is there still a role for axillobifemoral reconstruction? Semin Vasc Surg. 2011;24: 205-210. 10.1053/j.semvascsurg.2011.10. 011

94. Bakoyiannis CN, Georgopoulos SE, Tsekouras NS, Klonaris CN, Papalambros EL, Bastounis EA. Fungal infection of aortoiliac endograft: a case report and review of the literature. Ann Vasc Surg. 2007;21:228-231. 10.1016/j.avsg.2006.05.005

95. Chiesa R, Astore D, Piccolo G, Melissano G, Jannello $A$, Frigerio $D$, et al. Fresh and cryopreserved arterial homografts in the treatment of prosthetic graft infections: experience of the Italian Collaborative Vascular Homograft Group. Ann Vasc Surg. 1998;12: 457-462. 10.1007/s100169900184

96. Noel AA, Gloviczki P, Cherry KJ Jr, Safi H, Goldstone J, Morasch MD, et al. Abdominal aortic reconstruction in infected fields: early results of the United States cryopreserved aortic allograft registry. J Vasc Surg. 2002;35:847-852. 10.1067/mva.2002. 123755

97. Lesèche $G$, Castier $Y$, Petit $M D$, Bertrand $P$, Kitzis $M$, Mussot $S$, et al. Long-term results of cryopreserved arterial allograft reconstruction in infected prosthetic grafts and mycotic aneurysms of the abdominal aorta. J Vasc Surg. 2001;34:616-622. 10.1067/mva. 2001.116107

98. Bisdas T, Wilhelmi M, Haverich A, Teebken OE. Cryopreserved arterial homografts vs silver-coated Dacron grafts for abdominal aortic infections with intraoperative evidence of microorganisms. J Vasc Surg. 2011;53:1274-1281.e4. 10.1016/j.jvs.2010. 11.052

99. Neves JP, Gulbenkian S, Ramos T, Martins AP, Caldas MC, Mascarenhas R, et al. Mechanisms underlying degeneration of cryo- preserved vascular homografts. J Thorac Cardiovasc Surg. 1997;113:1014-1021. 10. 1016/S0022-5223(97)70286-1

100. Kieffer E, Gomes D, Chiche L, Fléron $\mathrm{MH}$, Koskas F, Bahnini A. Allograft replacement for infrarenal aortic graft infection: early and late results in 179 patients. J Vasc Surg. 2004;39:1009-1017. 10.1016/j.jvs.2003.12. 040

101. Chisci E, de Donato G, Setacci F, Stella A, Setacci C. Recurrent aortoenteric fistula: two different bridge solutions. Vascular. 2007;15:235-237. 10.2310/6670.2007. 00033

102. Sternbergh WC 3rd, Conners MS 3rd, Money SR. Explantation of an infected aortic endograft with suprarenal barb fixation. J Vasc Surg. 2003;38:1136. 10.1016/S07415214(03)00559-7

103. Chung J, Clagett GP. Neoaortoiliac System (NAIS) procedure for the treatment of the infected aortic graft. Semin Vasc Surg. 2011;24:220-226. 10.1053/j.semvascsurg. 2011.10.012

104. Ali AT, Modrall JG, Hocking J, Valentine RJ, Spencer $\mathrm{H}$, Eidt JF, et al. Long-term results of the treatment of aortic graft infection by in situ replacement with femoral popliteal vein grafts. J Vasc Surg. 2009;50:30-39. 10. 1016/j.jvs.2009.01.008

105. Pupka A, Skora J, Janczak D, Plonek T, Marczak J, Szydełko T. In situ revascularisation with silver-coated polyester prostheses and arterial homografts in patients with aortic graft infection-a prospective, comparative, single-centre study. Eur J Vasc Endovasc Surg. 2011;41:61-67. 10.1016/j.ejvs.2010.10.005

106. Lew W, Moore W. Antibiotic-impregnated grafts for aortic reconstruction. Semin Vasc Surg. 2011;24:211-219. 10.1053/j.semvascsurg. 2011.10.015

107. Campbell WB, Tambeur LJ, Geens VR. Local complications after arterial bypass grafting. Ann R Coll Surg Engl. 1994;76: 127-131.

108. Clagett GP, Valentine RJ, Hagino RT. Autogenous aortoiliac/femoral reconstruction from superficial femoral-popliteal veins: feasibility and durability. J Vasc Surg. 1997;25:255-266; discussion 267-270.

109. Reilly LM, Stoney RJ, Goldstone J, Ehrenfeld WK. Improved management of aortic graft infection: the influence of operation sequence and staging. J Vasc Surg. 1987;5: 421-431. 10.1067/mva.1987.avs0050421

110. Oderich GS, Bower TC, Hofer J, Kalra M, Duncan AA, Wilson JW, et al. In situ rifampin-soaked grafts with omental coverage and antibiotic suppression are durable with low reinfection rates in patients with aortic graft enteric erosion or fistula. J Vasc Surg 
2011;53:99-106, 107.e1-e7; discussion: 106-107. 10.1016/j.jvs.2010.08.018

111. Back MR. Local complications: graft infection. In: Cronenwett JL and Johnston W. Rutherford's Vascular Surgery, 7th Edition. Philadelphia: Saunders Elsevier; 2006, p. 643-661.

112. Stone P, Campbell J, Aburahma A, Safley L, Emmett M, Asmita M. Vascular surgical antibiotic prophylaxis study (VSAPS). Vasc Endovascular Surg. 2010;44:521-528. 10. $1177 / 1538574410373837$

113. Flora HS, Chaloner EJ, Sweeney A, Brookes J, Raphael MJ, Adiseshiah M. Secondary intervention following endovascular repair of abdominal aortic aneurysm: a single centre experience. Eur J Vasc Endovasc Surg. 2003; 26:287-292. 10.1053/ejvs.2002.1947
Cite this article as: Setacci $C$, Chisci $E$, Setacci F, Ercolini L, de Donato G, Troisi N, Galzerano G, Michelagnoli S. How To Diagnose and Manage Infected Endografts after Endovascular Aneurysm Repair. Aorta 2014;2(6):255-264. DOl: http:// dx.doi.org/10.12945/j.aorta.2014.14-036 